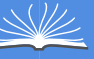

Global Journals In

(2)

\title{
Climate Change, South Asia and Southeast Asian Region
}

\author{
By Dr. Bir Abhimanyu Kumar \\ Indira Gandhi National Open University
}

Abstract- It is well known that the climatic conditions of our earth have changed since its origin. In its early days environmental conditions were not suitable for life. However, with due course of time it has changed and origin of life took place. Scientists have found seven cycles of glacial advance and retreat during the last 650,000 years and also that the last ice age abruptly ended about 7,000 years ago. The phenomenon of climate change has many implications and immense effects on our environment. There are many factors such as emissions of greenhouse gases, deforestation, urbanization and industrialization which impact the climate. Some of the major consequences of climate change include impacts on sea level rise in coastal areas, impacts on forestry, agriculture and food productivity, life and property in coastal areas, marine life, wildlife habitat and natural ecosystem, biodiversity, glaciers, floods and human health. This paper is an attempt to understand the phenomenon of climate change, historical evidences of climate change, identify reasons of global warming and climate change and its consequences in the South Asia and, in its neighbouring regions.

Keywords: climate change, global warming, impacts, south asia.

GJSFR-H Classification: FOR Code: 040199

Strictly as per the compliance and regulations of:

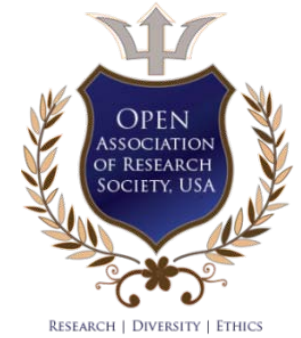

(C) 2020. Dr. Bir Abhimanyu Kumar. This is a research/review paper, distributed under the terms of the Creative Commons Attribution-Noncommercial 3.0 Unported License http://creativecommons.org/licenses/by-nc/3.0/), permitting all non commercial use, distribution, and reproduction in any medium, provided the original work is properly cited. 


\title{
Climate Change, South Asia and Southeast Asian Region
}

\author{
Dr. Bir Abhimanyu Kumar
}

Abstract- It is well known that the climatic conditions of our earth have changed since its origin. In its early days environmental conditions were not suitable for life. However, with due course of time it has changed and origin of life took place. Scientists have found seven cycles of glacial advance and retreat during the last 650,000 years and also that the last ice age abruptly ended about 7,000 years ago. The phenomenon of climate change has many implications and immense effects on our environment. There are many factors such as emissions of greenhouse gases, deforestation, urbanization and industrialization which impact the climate. Some of the major consequences of climate change include impacts on sea level rise in coastal areas, impacts on forestry, agriculture and food productivity, life and property in coastal areas, marine life, wildlife habitat and natural ecosystem, biodiversity, glaciers, floods and human health. This paper is an attempt to understand the phenomenon of climate change, historical evidences of climate change, identify reasons of global warming and climate change and its consequences in the South Asia and, in its neighbouring regions.

Keywords: climate change, global warming, impacts, south asia.

\section{InTRODUCTION}

T he entire South Asian region is one of the most densely populated regions in the world with very diverse climatic conditions. This region is also one of the most exposed and vulnerable regions in terms of the threats of experiencing major climate change. A considerable section of the South Asian population is heavily dependent on agriculture for their livelihood and they have to bear the consequences of the changing climate. The human population of South Asian region is estimated to increase up to 2.2 billion by 2050 , from the current population of about 1.5 billion. It has been estimated that nearly 600 million South Asian population belong to a very low income group, that means even a small impact of climatic change can cause irreversible damage pushing a large number of poor people into destitution. As per the World Bank report, the South Asian region has experienced significantly longer summers and in some cases severe heat waves, over the years. In recent times, the frequency of more intense rainfall has increased-leading to severe floods in low lying areas, landslides in hilly regions and debris flow in

Author: Deputy Director, Students Registration Division (SRD), Indira Gandhi National Open University (IGNOU) Maidan Garhi, New Delhi110068 (India).e-mail: abhimanyu.ignou@gmail.com many parts of the region. At the same time, the total amount of precipitation has declined in the region.

The main factor responsible for climate change over certain time period, is due to increase in the concentration of carbon dioxide $\left(\mathrm{CO}_{2}\right)$ gas and other global warming gases in the atmosphere. The increase in the concentration of $\mathrm{CO}_{2}$ and other Greenhouse gases (GHGs) has been caused due to increase in economic and other industrial activities, such as energy, industry, transport, and land use changes, many of which rely heavily upon burning of fossil fuels. The most important $\mathrm{GHG}$ is carbon dioxide $\left(\mathrm{CO}_{2}\right)$ that currently constitutes near about 77 per cent of the global warming potential. Another important contributors of global warming include emission of methane (from agricultural sources), and land use change such as deforestation. The concentration level of GHGs has increased due to the fact that emissions during the last two centuries were in excess of what could be naturally absorbed by the atmosphere, resulting in excess GHGs that began to accumulate in the atmosphere. The concentration level of $\mathrm{CO}_{2}$ alone has increased by nearly $100 \mathrm{ppm}$ over this period (Stern, 2006). The current level of global emissions contributes another 2-3 ppm of carbon dioxide equivalent $\left(\mathrm{CO}_{2}\right) \mathrm{GHGs}$ per annum.

\section{What is climate change?}

The climate of any region is the sum total (average) weather conditions of that geographical area. It includes rainfall, temperature variation, humidity and wind. The climate of any region is affected and influenced by many factors such as topography of the region, longitude, latitude, the tilt of the Earth's axis, proximity to the coastal areas, the movements of the wind belts and temperature differences between land and sea in the coastal areas. The term 'climate change' is synonymously used as 'global warming' and it refers to the rise in average temperatures on the Earth's surface. The term 'global warning' is generally used to describe a gradual increase in the average temperature of the Earth's atmosphere, oceans and is significant enough to permanently change the global climate.

The climate change is a multi-dimensional phenomenon and is affected by many factors in long time period. While many people consider the effects of global warming to be more rapid and more substantial than others do. The scientific consensus on climate changes related to global warming is that the average 
global temperature of the Earth has risen somewhere between 0.4 to $0.8^{\circ} \mathrm{C}$ during the last 100 years. Majority of the scientific community agrees that global climate change is primarily taking place due to the excessive burning of fossil fuels, which causes emission of carbon dioxide and other greenhouse gases (GHGs) into the atmosphere. The increased volume of $\mathrm{CO}_{2}$ and other greenhouse gases (GHGs) released by combustion of fossil fuels such as petroleum oil and coal, forest land clearing, agricultural activities and other human activities are believed to be the main sources of global warming that has occurred over the past 50 years.

The greenhouse gases have the capacity to trap solar heat energy within the atmosphere, which can have many adverse effects on our natural ecosystems, agriculture sector and human health. The climatic changes resulting due to the global warming may lead to the rise in sea levels in the coastal areas due to melting of the mountainous glaciers and polar ice caps, as well as an increase in occurrence and severity of floods, droughts, cyclones, typhoons, storms and other severe weather events.

The Fourth Assessment Report of the Intergovernmental Panel on Climate Change (IPCC, 2007) dispelled many uncertainties about climate change. The IPCC Report (2007) gave detailed projections for the $21^{\text {st }}$ century and these projections showed that the trend of global warming will continue further and may accelerate in future. Scientists associated with the Intergovernmental Panel on Climate Change (IPCC) carrying out researches on global warming have predicted that average global temperature could increase somewhere between $1.4^{\circ} \mathrm{C}$ and $5.8^{\circ} \mathrm{C}$ by the year 2100 . It has also been estimated that even if developed and developing countries make efforts to reduce their greenhouse gas emissions, the Earth will continue to warm further under the influence of climate change.

\section{The debate over climate change}

Many social activists advocating issues of climate change, politicians and scientists working on various aspects of climate change have diversified opinions and differ in their view points. They often debate within, between and among many other communities/people, sometimes even on the radio programmes, TV news channels and other platforms with regard to the problem of climate change- whether the climate change or global warming is real. Some of them opine and call it a hoax or hype to benefit a few select stakeholders. However, within the scientific community across the nations, there is broad-based consensus and agreement that the phenomenon of climate change is real. Most of the researchers and scientists doing research on climate change and engaged in analyzing the available data and facts agree that the planet Earth is gradually warming. Many ogranisations such as the U.S. Environmental Protection Agency, National Aeronautics and Space Administration, National Oceanic and Atmospheric Administration and other scientific agencies/organizations doing scientific research and working on climate change agrees that climate change is indeed occurring and is almost certainly due to the increased emissions of $\mathrm{CO}_{2}$ and other greenhouse gases (GHGs) from various anthropogenic activities.

It is very interesting to see that while consensus among all the researchers, scientists, scientific organizations, and government agencies is that climate change is actually happening. It is also agreed that the global warming is mainly caused by industrial gaseous emissions and other human activities. There are certain organizations, pressure groups and individuals, although small in number, are questioning the validity of such assertions and prefer to cast doubt on the occurrence of evidences on climate change. Those who argue against the problems of climate change or global warming often claims that recent changes in climate can be mainly attributed to human activities and can be seen as a part of the natural variations in the Earth's climate and temperature. They also argue that it is extremely difficult or almost impossible to establish a direct relationship between climate change and any single weather event, such as a floods, typhoon or hurricane. While the latter is generally true, however decades of climate data analysis supports the reality of climate change and the role of human factor in this process. In any case, economists generally agree that initiatives and preventive measures taken to reduce or minimize industrial and fossil fuel emissions would be far less expensive than dealing with the consequences of not doing so.

\section{Evidences of Climate change}

There is no doubt that the climate has changed throughout the Earth's history since the formation of our planet. Based on the evidences, scientists have found that during the last 650,000 years there have been seven cycles of glacial advance and retreat. They have also found that the last ice age abruptly came to an end about 7,000 years ago. The sudden and abrupt end of the ice age also marked the beginning of the modern climatic era and of human civilization. Most of these climate changes are attributed to very small variations in Earth's orbit that change the amount of solar energy our planet receives.

The detailed scientific researches on climatic events during the past 150 years have revealed that the average atmospheric temperature has risen all over the globe. It has also been observed that the global warming has occurred in two distinct phases- the first phase has been estimated to be from 1919 to 1940 , with an average temperature gain of about $0.35^{\circ} \mathrm{C}$. The second phase of global warming has been estimated to 
be from 1970 to the present, exhibiting temperature gains of about $0.55^{\circ} \mathrm{C}$. The oceans water has absorbed much of this increased heat, with the top 700 meters (about 2,300 feet depth) of ocean water showing warming of nearly 0.302 degrees Fahrenheit since 1969. The records of climate change also show that the last 25-30 years have been the warmest time of the past five centuries. The global warming has caused the rise in average temperature of the oceans, rising of the sea levels, melting of ice glaciers, and diminishing of snow cover in the Northern and Southern Hemisphere. Observations by remote sensing satellites also reveal that the amount of spring snow cover in the Northern Hemisphere has decreased over the past five decades and that the snow is melting earlier. The current warming trend is of particular significance because most of it is extremely likely (greater than 95 percent probability) to be the result of anthropogenic activities since the mid$20^{\text {th }}$ century and proceeding at a faster rate that is unprecedented over decades to millennia.

The earth-orbiting remote sensing satellites and other technological advances have enabled scientists to see the larger picture, facilitating collection of many different types of scientific data, information and its analysis about our planet and its climate on a global scale. This large volume of data and information collected over many years has clearly revealed the signals of a changing global climate.

The heat-trapping properties of carbon dioxide and other such greenhouse gases were demonstrated in the mid- $19^{\text {th }}$ century. Their property to affect the transfer of infrared energy through the atmosphere is the scientific basis of many instruments flown by NASA. There is no doubt that the increased concentration of greenhouse gases has led to the warming of the Earth's atmosphere in response.

Ancient evidences related to climate change can also be found in tree rings, ocean sediments, coral reefs, and layers of sedimentary rocks. This ancient or paleo-climate evidences reveals that current rate of global warming is occurring roughly ten times faster than the average rate of ice-age-recovery warming. The scientific analysis of ice cores drawn from Greenland, Antarctica and mountain glaciers in tropical regions shows that the Earth's climate responds to atmospheric changes in levels of greenhouse gases.

The scientific studies in recent times suggest that during the last century, the global sea level has risen to about 8 inches. It has also been observed that the rate in the last two decades, however, has nearly double as compared to the last century.

The scientific researches also reveals that the Earth's average surface temperature has risen to nearly 2.0 degrees Fahrenheit (1.1 degrees Celsius) since the late $19^{\text {th }}$ century, which is largely driven by the increased levels of carbon dioxide and emissions of other GHGs into the atmosphere. These studies further suggest that most of the global warming has occurred during the past 35 years, with 16 of the 17 warmest years on record occurring since 2001. The year 2016 was not only the warmest year on record, but eight of the 12 months that make up the year from January through September, with the exception of June, were the warmest on record for those respective months.

It has also been observed that the mass of ice sheets in Greenland and Antarctic have decreased in recent times. Scientific data from NASA's Gravity Recovery and Climate Experiment show that Greenland has lost nearly 150 to 250 cubic kilometers (36 to 60 cubic miles) of ice per year between 2002 and 2006, while Antarctica has lost about 152 cubic kilometers (36 cubic miles) of ice between 2002 and 2005. Over the last several decades, both the extent and thickness of Arctic sea ice has rapidly declined.

There are various studies showing that mountain glaciers are retreating almost everywhere around the world, including glaciers in the Africa, Andes, Rockies, Alaska, Alps and Himalayan mountain ranges.

It has been noticed that the United States has witnessed increasing numbers of intense rainfall events in the last six decade. It has also been observed that since 1950s, the number of record high temperature events in the United States has been increasing, while the number of record low temperature events has been decreasing.

The acidity of surface ocean waters has increased by nearly 30 percent since the beginning of the Industrial Revolution, which is the result of anthropogenic emission of more carbon dioxide into the atmosphere and hence more being absorbed into the oceans. The amount of carbon dioxide absorbed by the upper layer of the oceans is increasing by about 2 billion tons per year.

\section{What are the causes of climate change?}

The burning of fossil fuels, such as petroleum oil and coal, which emits greenhouse gases into the atmosphere, mainly carbon dioxide are considered as the primary causes of climate change. Other anthropogenic activities such as burning of agriculture residue and deforestation also contribute to the increased concentration of greenhouse gases that causes climate change.

As suggested by various scientific studies, it is now clear that climate change related to global warming is mostly happening due to increased emissions of greenhouse gases (mostly $\mathrm{CO}_{2}$ ). Over the last century, atmospheric concentrations of carbon dioxide has increased from a pre- industrial value of about 278 parts per million (ppm) to nearly 379 parts per million (ppm) in the year 2005. During the same period, the average global temperature rose by about $0.74^{\circ} \mathrm{C}$. According to scientists, this is the largest and fastest warming trend in the history of the Earth that they have been able to 
discern. The World Meteorological Organisation (WMO) Greenhouse Gas Bulletin showed that globally averaged concentrations of carbon dioxide $\left(\mathrm{CO}_{2}\right)$ reached 407.8 parts per million in 2018, up from 405.5 parts per million (ppm) in 2017.

The increase in $\mathrm{CO}_{2}$ from 2017 to 2018 was very close to that observed from 2016 to 2017 and just above the average over the last decade. Global levels of $\mathrm{CO}_{2}$ crossed the symbolic and significant 400 parts per million benchmark in 2015.

Some quantities of these global warming gases are naturally occurring and are critical part of Earth's temperature control system. It is significant to notice that the atmospheric concentration of $\mathrm{CO}_{2}$ did never rise above 300 parts per million (ppm) between the advent of human civilization roughly 10,000 years ago and 1900. But in recent times, it's concentration in the atmosphere has reached to about 400 parts per million (ppm), a level never reached in more than 400,000 years in the Earth's history and is the main cause of global warming.

It has been observed that an increasing rate of global warming has particularly taken place over the last 25-30 years. It has also been observed that 11 of the 12 warmest years on record have occurred during the past 12 years.

\section{il. Consequences of Climate Change}

It has been estimated that the South Asia and Southeast Asian countries will be among the regions hardest hit by the consequences of climate change. Countries like Bangladesh, India, Vietnam and Sri Lanka in particular, will feel the impacts of climate change acutely due to large coastline. Climate change resulting due to rising temperatures is expected to cause more extreme weather events, rising sea levels, increasing cyclonic activity in the Bay of Bengal and the Arabian Sea. It may also cause floods in the region's complex river systems that will affect the existing development and poverty reduction initiatives. Coupled with high population density levels, these climate shifts have the potential to create complex environmental, humanitarian, and security challenges.

The IPCC $4^{\text {th }}$ Assessment Report states that South and Southeast Asia is expected to be severely affected by the adverse impacts of global climate change since economies of most countries in the region are relying heavily on agriculture and natural resources. South Asia and Southeast Asian region is annually witnessing events of climate extremes, particularly droughts, floods and tropical cyclones. At the same time large areas of the region are influenced by monsoon and highly prone to flooding.

It is expected that in the next 30 to 50 years, the Southeast Asia will face the worst impacts of global warming. Consequently, such climatic impacts will severely threaten the livelihood of poor people living in rural and coastal areas with limited adaptive capacity. According to recent predictions, increased global warming is expected to significantly impact working people and productivity in Southeast Asia by 2045. Rising temperature will also increase the no. of unsafe 'heat stress' days annually, which will adversely affect vulnerable workers, and have a negative impact on regional economies.

The changes in the global climate will have sever and wide-ranging impacts on our natural environment, water resources, food supply, land, infrastructure and the increase in extreme weather events, socio-economic activities and related sectors. It would also affect our natural biodiversity, terrestrial/aquatic ecosystems, agriculture productivity and food security, human health and coastal zones. The predicted changes in rainfall pattern due to climate change (spatial and temporal) are likely to severe water shortages or cause flooding in many areas.

Due to rise in temperature, melting of mountainous ice glaciers can cause soil erosion and flooding downstream. The rise in atmospheric temperatures may cause shifts in crop growing seasons and cropping pattern which may affect food security. Increasing temperature due to global warming has the potential to severely increase rates of extinction for many natural habitats and vulnerable species (projected up to 30 per cent loss with a $2^{\circ} \mathrm{C}$ rise in temperature). This would particularly affect coral reefs, boreal forests, Mediterranean and mountain habitats. Increasing sea levels in coastal areas mean greater risk of storm surge, inundation and damage to coastlines due to high waves, particularly in small islands and countries with low lying deltas.

Based on IPCC Reports and various studies, the probable and projected impacts of global climate change on some of the main sectors such as impacts of global warming on sea level rise, biodiversity, glaciers, floods, agriculture and human health in the South Asia and Southeast Asian region have been discussed below.

\section{ili. Sea level in Coastal Areas}

The South Asian region (SAR) is extremely vulnerable to sea level rise, cyclone, floods, droughts and landslides in hilly areas. The remote and rural areas have low access to clean and modern efficient energy services. So, even small increases in Earth's temperature caused by climate changes can have severe impacts on them. It has been estimated that the earth's average temperature has gone up by $1.4^{\circ} \mathrm{F}$ over the past century and is expected to rise as much as $11.5^{\circ} \mathrm{F}$ over the next century. This might not seem like a lot, but the average global temperature during the last Ice Age was about $4^{\circ} \mathrm{F}$ lower than it is today. 
The rising sea levels due to melting of polar ice caps contribute to greater storm damage; warming ocean temperatures are associated with stronger and more frequent storms. Increased rainfall, particularly during severe weather events, may leads to flooding and may cause damage to life and infrastructure. An increase in the incidence and severity of wildfires threatens natural biodiversity, habitats, homes and lives; heat waves may contribute to human deaths and other consequences.

As reported by IPCC various studies have projected that sea level rise could flood the coastal residential areas of millions of people living in the low lying areas of South, Southeast and East Asia such as in Sri Lanka, Vietnam, Bangladesh, India and China (Wassmann et al. 2004, Stern 2006, Cruz et al. 2007). A rising sea levels due to global warming will increase the amount of loss of land and people displaced due to permanent inundation in the coastal areas. It might also have some major impacts on national, regional and even the global economy, as coastal areas are not only amongst the most densely populated areas, but in many cases are the location of some of the critical infrastructure such as sea ports, industrial facilities, oil refineries, etc.

Already global warming has resulted in an increased cyclonic activity, sea level rises displacing people, flooding, and the reduction in the sea food due to the acidification of the waters. Thousands of people have been displaced by ongoing sea level rises that have submerged low-lying islands in the Sundarbans. A one meter sea level rise is projected to displace approximately 7.1 million people in India and about $5,764 \mathrm{Km}^{2}$ of land area will be lost, along with $4200 \mathrm{Km}$ of road. Around seven million people are projected to be displaced due to submersion of parts of Mumbai and Chennai if global temperatures were to rise by as low as $2^{\circ} \mathrm{C}$.

\section{Agriculture}

An assessment report (2009) released by the International Fund for Agricultural Development (IFAD) predicted that in the South and Southeast Asia, agriculture and natural resource management will be seriously affected by the adverse impacts of climate change. According to IFAD report, events of climate extremes, such as droughts, floods and cyclones, would severely impact irrigation systems, soil degradation, loss of natural ecosystems, crop productivity, crop yields, loss of natural wild life habitat and fresh water resources. This will have adverse impacts on developing and underdeveloped countries such as India, Sri Lanka and Bangladesh, relying heavily on agriculture and natural resources. These climate impacts will also severely threatens livelihoods of local people, depending extensively on agricultural production.
In the same year, the Asian Development Bank (ADB) released a report on the economics of climate change in Southeast Asia. According to the ADB report (2009), Southeast Asia is particularly vulnerable to climate change, due to large number of the population living under poverty, its heavily populated coastlines and large agricultural sectors.

The agriculture sector accounted for nearly 43 percent of total employment in 2004, and contributed to about 11 percent of GDP in 2006, within the Southeast Asian region. The region is also highly dependent on natural resources and forestry products and these exports are likely to be adversely affected by extreme weather events due to climate change.

The Asian Development Bank report further predicted that rice yields were likely to decline by up to 50 percent on an average by the year 2100 compared to 1990. Many countries such as Vietnam and Thailand are expected to be the most affected by this decline. In addition, rising sea levels could also result in the loss of about 12 percent of rice production in the region. The climate change is expected to adversely affect the agriculture sector in South and Southeast Asia in several ways. For example, changes in rainfall and runoff, and subsequently, water quality and water supply may severely affect irrigation systems in the region. The region is already under water stress and future climate change effects on regional rainfall will therefore have both direct and indirect impacts on agriculture productivity.

As per predictions, when the region is facing 2$4{ }^{\circ} \mathrm{C}$ temperature changes, studies suggest the potential for both gains and losses. For example, for less than 2 ${ }^{\circ} \mathrm{C}$, agricultural losses are experiences in the Philippines, while rice yields in Indonesia and Malaysia are projected to increase.

However, climate change studies generally indicate increasing rainfall throughout much of the region. But even with rainfall increases, temperature increase may threaten agricultural productivity, stressing crops and reducing yields. The scientific studies have projected, particularly, a high sensitivity of major cereals and tree crops due to changes in temperature, moisture, and carbon dioxide concentration for the region. As for example, projected impacts on rice and wheat yields indicate that any increases in production associated with $\mathrm{CO}_{2}$, fertilization will be more than offset by reductions in yield resulting from temperature and/or moisture changes. Such agricultural impacts would particularly affect low-income rural population that depends on traditional agricultural systems or on marginal lands for their livelihood. The food security for the people is the primary concern in the region since most of the rural poor people depend heavily on agriculture for their livelihood. 
The global warming is causing changes in the intensity of rainfall events, and the break cycles of the monsoon, combined with an increased risk of critical temperatures being exceeded more frequently, could significantly change cropping pattern and crop yields. In fact, spatial and temporal changes in the temperature coupled with water stress will have key implications for agriculture production, in particular, for falling crop yields. The impacts of climate change on agriculture will vary according to locality, but models project a 15-30\% decline in the crop productivity of most cereals and rice across the region. For example, when the region is facing with $2-4^{\circ} \mathrm{C}$ temperature increase, rice yields are expected to decline by about 0.75 tons/ha.

The studies have also shown that the overall crop yields are expected to decrease up to $30 \%$ in the region by mid $21^{\text {st }}$ century. The most dramatic negative impacts are expected in the arid zones and flood affected areas, where agriculture is already at the edge of climate tolerance limits. Furthermore, the demand for water for irrigation of agricultural fields in arid and semiarid regions is likely to increase by about $10 \%$ for temperature increase by $1 \%$.

It has been estimated that even though the impact of climate change could cause significant changes in crop production, crop yields, storage and distribution. The ultimate effect of the climatic changes in the region is uncertain mainly because of local differences in crop growing season, crop irrigation, crop management, etc. The non-inclusion of possible crop diseases, microorganisms affecting crops and pests, in crop model simulations and the vulnerability of agricultural areas to episodic environmental hazards, including floods, droughts and cyclones also affects the outcome. In such situation, low-income rural population that rely on traditional agricultural systems or on marginal lands are particularly vulnerable to the impacts of climate change (IPCC $4^{\text {th }}$ Assessment report).

\section{Ecosystems and Biodiversity}

In recent years, natural ecosystems in South and Southeast Asia's have been put under enormous pressures to support the ever growing demand for supply of direct and indirect consumable materials due to increasing population, industrial activities, urbanization, demand for timbers, etc. The most affected areas are coastal and marine ecosystems, natural forests, mountainous regions, flora and fauna within them. The climate change will have a profound effect on the future distribution, productivity, and health of forests throughout Asia and Southeast Asia, as for example, northeast China may become deprived of conifer forest. It has been estimated that the productivity of grassland ecosystem is expected to decline by as much as 40-90 per cent for an increase in average temperature of about $2-3^{\circ} \mathrm{C}$, combined with reduced precipitation, in the arid and semi-arid regions.
There are various studies that reveal that in the $20^{\text {th }}$ century global warming has already directly affected our natural ecosystems, as for example, many species have been moving pole-wards, seasonal events such as flowering or egg-laying have been occurring several days earlier each decade. The bleaching of Coral reefs has become increasingly prevalent since the 1980s. It has also been estimated that nearly 30 percent of coral reefs could be lost in the next 10 years (Cruz et al. 2007). The loss may be as high as 88 per cent (59 per cent of global) in the next 30 years in some areas (Sheppard 2003; Wilkinson 2004). Overall it is estimated that global climate change has already contributed to the extinction of over $1 \%$ of the world's amphibian species from tropical mountains.

In the future, it is expected that for many species, the rate of warming will be too rapid and too high to withstand the changes. A warming world due to climate change will also have severe consequences for many species as it will accelerate species extinctions and has the potential to lead to the irreversible loss of many vulnerable and endangered species around the world, with most kinds of animals and plants affected. The rising levels of carbon dioxide have some direct impacts on natural ecosystems and rich biodiversity, but increases in temperature and changes in rainfall pattern will have even more profound effects. Many endangered, rare and vulnerable species in natural ecosystems are likely to disappear almost completely at even moderate levels of global warming.

Natural ecosystems and its rich biodiversity in the South and Southeast Asia region represent a key asset contributing to the regional economy by providing food, water and other products that sustain human life. Natural resources such as medicinal plants, timber products and fisheries also support commercial enterprises in the entire region. As a result the degradation and loss of natural ecosystems poses a serious threat to the economic, social and cultural stability of the region since most of the poor and rural community is heavily dependent upon the products of such ecosystems. The survival of many species has already been threatened due to land-use changes, land degradation, loss of biodiversity, over-exploitation of water resources and other natural resources, contamination of inland and coastal water bodies.

Many scientific studies suggests that climate change leading to sea level rise, increasing sea surface temperatures and acidification of the oceans will entail a loss of mangrove forests, wetlands, and reduced fish stocks throughout this region. The tropical and temperate forests are particularly affected due to climate change. Coral reefs may be able to keep up with the rate of sea-level rise but may suffer bleaching from higher temperatures. For example, the 1997-1998 El Nino event caused widespread bleaching of coral reefs in the Southeast Asian region including Indonesia, 
Cambodia, Malaysia and Thailand. Landward migration of mangroves and tidal wetlands is expected to be constrained by infrastructure and human activities (IPCC $4^{\text {th }}$ Assessment report).

The mangrove communities are severely affected by sea-level rise, change in rainfall patterns and runoff that change the flow of freshwater to the coastal zone and, consequently, the distribution of proper saline habitat for mangroves forests. The projected increases in the rate of evapo-transpiration and rainfall variability are likely to have a negative impact on the viability of freshwater wetlands, resulting in shrinkage and desiccation.

Several studies on climate change also suggest that some of the natural forests and vegetation in South and Southeast Asia may experience some positive effects due to climate change. In addition, climate change is expected to change disturbance regimes within forest communities, affecting the frequency and intensity of pest outbreaks and wildfire. The expected changes in the distribution and health of rainforest and drier monsoon forest will be complex, for example, in Thailand the area of tropical forest could increase from $45 \%$ to $80 \%$ of total forest cover (Boonpragob, K., Santisirisomboon, J., 1996).

Anthropogenic pressures together with changing hydrology are having a discernible impact on the productivity and resilience of South Asia's ecosystems. Some of the most significant sites threatened by global warming, are the Terrai grasslands, forests of the southern Himalayas, biosphere in the Western Ghats; and the Sundarbans wetlands of West Bengal and Bangladesh. The mountain ecosystems are expected to be the most affected by the climate change. The Himalyan ecosystems are vulnerable to Glacial Lake outburst, floods and flash floods.

The changes in the forest distribution, health of rainforest and drier monsoon forest are foreseen. In Sri Lanka, for example, a significant increase in dry forest and a decrease in wet forest could occur. Moreover, increased dryness during pre-summer season may speed up the incidences of forest fire. Potential increases in evapo-transpiration and rainfall variability are expected to have a negative impact on the viability of freshwater wetlands, resulting in shrinkage and desiccation. In particular, regional studies have projected a loss of about $54,900 \mathrm{~km}^{2}$ of wetland in the region. Sea-level rise and increases in sea-surface temperature are the most probable major climate change-related stresses on coastal ecosystems.

\section{Vi. Coastal Areas}

The coastlines of South Asia and Southeast Asia are highly vulnerable to the effects of climate change due to the geology and geography of the region's coastal areas, the growing population density and presence of coastal infrastructure in the coastal zone. Moreover, large tidal variations, tropical cyclones, coupled with the potential increase in regional rainfall, suggest the probability for increased coastal hazards.

Sea-level rise and increases in sea-surface temperature are the most probable major climate change-related stresses on coastal ecosystems. Densely populated, heavily settled and intensively used low-lying coastal plains, deltas and islands are especially vulnerable to coastal erosion, land loss, inundation and sea flooding, upstream movement of the saline/freshwater front and seawater intrusion into freshwater aquifers. The impacts of sea level rise will be mostly felt in low-lying areas of Indonesia, Philippines, Myanmar, Vietnam, Thailand and Malaysia as well as large deltaic regions of Bangladesh, Maldives and east India by poor rural people, where significant economic and social disruption will occur, with environmental refugees further pressing already stressed cities.

The consequences of climate change will change conditions and undermine livelihoods in many areas. The World Bank issued a press release (2013), warning that warmer weather due to rise in temperature, could threaten livelihoods in Southeast Asia. It predicted the degradation of coral reefs, which is likely to diminish tourism, reduce fish stocks and leave coastal communities more vulnerable to storms. The World Bank's 2014 report released by the Intergovernmental Panel on Climate Change (IPCC), warned that people living in coastal regions of Asia could face some of the worst effects of global warming. It is expected that millions of vulnerable people living in these areas are likely to lose their shelter, homes and settlements due to flooding and famine. The extreme climate events and deteriorating environmental conditions are likely to force many to leave their homes temporarily or even permanently for another village, city, region or country.

Socio-economic impacts could be felt in major coastal cities, ports and tourist resorts, commercial and small scale fisheries, coastal agriculture and infrastructure development. Other consequences will include increased salinization of surface water and groundwater, loss of wetlands such as the Sundarbans and public health risks. International studies have projected the displacement of several million poor people from the region's coastal zone, even in the event of a $1 \mathrm{~m}$ rise in sea level. The costs of response measures expected to reduce the probable impact of sea-level rise $(30-50 \mathrm{~cm})$ in the region could amount to millions of dollars per annum (IPCC $4^{\text {th }}$ Assessment report).

\section{Vil. Cyclones}

India has a long coastline of about $7500 \mathrm{~km}$, with the Arabian Sea and the Bay of Bengal and is 
therefore, very susceptible to cyclonic activity. The coastal areas of India are densely populated with people who are totally dependent on the sea for their economies and food supply, as a result highly vulnerable to the effects of global warming. Therefore, any damage to the natural cycle of the sea is expected to severely affect the people of coastal India. Cyclones have been observed to be more frequent in the Bay of Bengal than the Arabian Sea. Consequently the states of Andhra Pradesh, Orissa, Tamil Nadu and West Bengal, along the Bay of Bengal are the most affected areas due to cyclone. Some of the most notable cyclones in Indian history include the 1737 Hooghly/Calcutta cyclone, 1970 Great Bhola cyclone, 1839 Coringa Cyclone and 1876 Great Backerganj Cyclone which affected more than a million people. It has also been observed that as a result of global warming, the average number of Category 4 and Category 5 hurricanes per year has increased over the last 30 years.

The National Institute of Oceanography (NIO), under the Council of Scientific and Industrial Research (CSIR), Government of India, carried out a scientific research on the impacts of climate change on sea level, to assess the degree to which mean sea level changes and the occurrence of extreme events may change. The study concluded that an increased occurrence of cyclones in the Bay of Bengal, particularly in the postmonsoon period, along with increased maximum wind speeds associated with cyclones and a greater number of high surges under climate change have been observed. In addition, the strength of tropical cyclones, which represent a threat to the eastern coast of India and coastal area of Bangladesh, is also likely to increase.

\section{Vili. Migration of People}

Although the precise influence of climate change on migration of people is not known and is still the subject of scientific inquiry and debate. The range of issues facing the region calls for a comprehensive assessment of climate change, migration, and their impact on both traditional and human security. The Asian Development Bank report (2012) "Climate Change and Migration in Asia and the Pacific" concludes that while uncertainties exist on where, how and how many people will be displaced by the impacts of climate change, it is imperative to begin aggressively examining emerging climate challenges to avoid future complex crisis scenarios. The extreme vulnerability of South Asia and Southeast Asia raises concern of potential changes and increases in both internal and international migration across the subcontinent. In areas of existing conflict in South Asia and Southeast Asia added stressors of climate change and changing migration patterns could be a security concern.

The deteriorating environmental conditions could increasingly influence decisions to migrate, in addition to social, political, economic and demographic factors. Sudden onset and slow-onset of climate change events could trigger migration in Bangladesh, India, Sri Lanka, Vietnam and other neighbouring countries. It is also expected that sudden-onset of climatic events such as flooding, cyclones and storm surges could displace millions of inhabitants within short periods of time, as recent events in India and Bangladesh demonstrate. The slow-onset of climatic events such as changes in precipitation, sea level rise and land erosion could have detrimental impacts on some of the key economic sectors such as agriculture, fishing and tourism, influencing someone's decision over time to migrate for greater economic opportunity.

Recent natural disasters in South Asia demonstrate what could be a more frequent reality for the region. Floods in September 2012 displaced about 1.5 million people in the northeastern state of Assam, while Cyclone Aila in 2009 displaced nearly 2.3 million people in India and almost 850,000 people in Bangladesh.

\section{iX. Water Resources}

The impact of climate change is most strongly felt through changes in the distribution of water around the world and differences in water availability between regions will become increasingly difficult. The region already faces water stresses and many areas are often dependent upon limited availability of groundwater and rainfall collection. Maintaining the security of fresh water resources is a key priority for the South Asia and Southeast Asian poor rural population. Climate change will further aggravate water shortage by extreme events such as droughts which undermine food security, or extreme rainfall events which increase the risk of flooding. Challenges to water resources management will therefore be exacerbated by sea-level rise which contribute to salt-water intrusion into available freshwater resources in the coastal areas. Scientific assessments have projected changing patterns of runoff and river flows in the region in the next decades, as well as increase in water management costs and number of poor rural people affected by water stress.

In particular, a reduction in flow of snow-fed rivers, coupled with increases in peak flows and sediment yields, may have serious implications on hydropower generation, urban water supply and agriculture. Water availability from snow-fed rivers could increase in the short term but decrease in the long term. Runoff from rain-fed rivers may change in the future, although a reduction in snowmelt water would result in a decrease in dry-season flow of these rivers. The requirements of water for larger populations and increasing demands in the agricultural, industrial, and hydropower sectors will put additional stress on available water resources. The pressure will be most 
evident on drier river basins and those subject to low seasonal flows.

Availability of fresh water is highly seasonal, with about $75 \%$ of the annual rainfall occurring during the monsoon months. Water supplies will be threatened by higher temperatures, changes in river regimes, and greater incidence of coastal flooding. In particular, water availability is expected to decrease dramatically especially in dry season. The main consequences of expected climate change impact is melting of glacier in Himalayas, which is projected to increase flooding and affect water resources aggravating seriously the conditions of poor rural people reliant on them. Water from Himalayan glaciers - which plays a key role in the provision of water to the region and snowfields currently supplies up to $85 \%$ of the dry season flow of the great rivers of the Northern Indian Plain. This could be reduced to about $30 \%$ of its current contribution over the next 50 years, if forecast of climate change and glacial retreat are realised. This will have major implications for water management and irrigated crop production.

Furthermore, temperature and increased seasonal variability in precipitation are projected to result in accelerated recession of glaciers and increasing risk from glacial lake outburst floods. A reduction in flow of snow-fed rivers, accompanied by increases in peak flows and sediment yields, would have major impacts on hydropower generation, water supply, and agriculture.

Hydrological changes in island and coastal drainage basins are expected to be small, apart from those associated with sea-level rise. However, national studies suggest for both gains and losses due to projections of increased runoff in some river basins in response to increasing rainfall. For example, water stress in the Mekong Delta rises, and water shortages in the Philippines may fall. As per the IPCC $4^{\text {th }}$ assessment report, regional studies state that a loss of 1.7 billion USD in total costs in the water resources sector is associated to projected $2 \%$ temperature increase, and an increase by 7-924 million of the number of poor rural people experiencing water stress associated to $2-4 \%$ of temperature increase (IPCC $4^{\text {th }}$ Assessment report).

\section{Floods and Droughts}

Under climate change scenario, predicted rainfall increases over most of Asia and Southeast Asia region, particularly during the summer monsoon. This could further increase flood-prone areas in East Asia, South Asia and Southeast Asia. In Central and South Asia, crop yields are predicted to fall by up to 30 per cent, creating a very high risk of hunger in several countries.

The entire South Asian region suffered from flood in 2007 that was so devastating, that it annihilated and destroyed large areas in Bangladesh, Nepal,
Bhutan, India and Pakistan. It's most devastating effects were observed in Southern India, where it lasted for more than 15 days, killing more than 2000 people and affecting another nearly 30 million people. The situation was termed by UNICEF to be 'the worst flooding of South Asian region in living memory'.

The recent catastrophic climatic events such as the massive floods in India and Pakistan, Hurricane Katrina in the United States, prolonged droughts in Australia, China, India, Pakistan and Texas in United States, are all the results of increased temperatures due to global warming. It has been noticed that during the $21^{\text {st }}$ century, climatic disasters has occurred five times as frequently and killed or affected nearly seventy times as many people. Research studies have also indicated that between the year 2000 and 2004, an average of 26 climatic disasters was reported each year. Thus, the extreme climatic events will continue their destruction unabated if steps to mitigate the impacts of global warming are not taken at the earliest and in an effective manner.

As explained above, the process of global warming has such an impact on the climate that it increases the severity of precipitation at one time, and minimizes it in the other. Therefore, this process has resulted in severe drought like conditions in India, with tens of millions of deaths resulting from it in the past few centuries. India depends heavily on prolonged and optimum monsoons for its agricultural productivity, failure of which results in the decreased crop productivity, leading to droughts. Out of the total agricultural land in India, about $68 \%$ is prone to drought of which $33 \%$ is chronically drought prone, receiving rainfall of less than $750 \mathrm{~mm}$ per year, particularly in the states of Maharashtra, Gujarat, Rajasthan, Karnataka, Andhra Pradesh and Orissa. The World record of drought was in 2000 in Rajasthan, India. According to researches, unabated global warming will lead to exacerbation of the droughts, cutting down the water availability in the plains of Uttar Pradesh and Bihar. India's initial communication to the United Nations Framework Convention on Climate Change (UNFCCC) projected that Luni, the west flowing river of Kutchh and Saurashtra are likely to experience acute physical water scarcity. The river basins of Mahi, Pennar, Sabarmati and Tapi are also likely to experience constant water scarcities and shortages.

\section{Glaciers}

As discussed earlier, global warming is causing the melting of ice glaciers in the Himalayas and other ice deposits. In the short term, this means increased risk of flooding, soil erosion, mudslides, landslides and Glacial Lake Outburst Flood (GLOF) in Nepal, Bhutan, Bangladesh, Pakistan, and north India during the wet season. The term 'GLOF' refers to the glacier floods 
caused by the drainage of naturally dammed lakes in the glaciers on/at the margin of glaciers. Because the melting of snow coincides with the summer monsoon season, any intensification of the monsoon and/or increase in melting is likely to contribute to flood disasters in Himalayan catchments.

In the longer term, global warming could lead to a rise in the snowline and disappearance of many glaciers causing serious impacts on the populations relying heavily on the 7 main rivers in Asian region fed by glaciers melt water from the Himalayas. Throughout Asia one billion people could face water shortage leading to drought and land degradation by the year 2050s (Christensen et al. 2007, Cruz et al. 2007).

\section{HEALTH}

Human health will be strongly affected by climate change, as worldwide deaths from malnutrition and heat stress are likely to increase and vector-borne diseases could become more widespread. A rise in extreme weather events will have severe effects on health and lives as well as associated environmental and economic activities. The changes in the distribution of vectors borne diseases may bring more people at risk from diseases such as high fever due to dengue, malaria and chikungunya.

According to $\mathrm{WHO}$ assessment report, climate change affects the social and environmental determinants of health such as clean air, fresh and safe drinking water, sufficient food and secure shelter. Between 2030 and 2050 climate change is expected to cause approximately 250,000 additional deaths/year from malnutrition, malaria, diarrhea and heat stress.

In Asia, the principal impacts of climate change on health will be on epidemics of malaria, dengue, and other vector-borne diseases (Martens et al. 1999). The global burden of climate change-attributable diarrh0oea and malnutrition are already the largest in the world in Southeast Asian countries including Bangladesh, Bhutan, Nepal, India, Maldives and Myanmar in 2000. Illness and death are expected to increase from diarrhoea diseases due to drought and flooding, and are also expected from increased amounts of cholera bacteria in coastal waters. Climate change leading to an increase in the frequency and duration of severe heat waves and humid conditions during the summer season is likely to increase the risk of mortality and morbidity, mainly in the old and urban poor populations of temperate and tropical Asia (Epstein et al. 1995) and high temperatures and poor urban air quality, such as in Chongqing, China and in Jakarta, Indonesia, could contribute to widespread heat stress and smog induced illnesses in urban populations (Cruz et al. 2007).

\section{Xili. IMPACTS ON PRODUCTIVITY}

According to the Indira Gandhi Institute of Development Research, if the process of global warming continues to increase, resulting climatic disasters would cause a decrease in India's GDP to decline by about $9 \%$, with a decrease by $40 \%$ of the production of the major crops. A temperature increase of $2^{\circ} \mathrm{C}$ in India is projected to displace seven million people, with a submersion of the major cities of India like Mumbai and Chennai. The Asian Disaster Preparedness Center recently reported that Bangladesh "is already under pressure from increasing demands for food and the parallel problems of depletion of agricultural land and water resources from overuse and contamination. Climate variability and projected global climate change makes the issue particularly urgent."

Worst hit will be Singapore and Malaysia, which could experience decreases in productivity by up to 25 per cent. Expected decreases in productivity will vary across the region, with Indonesia predicted at 21 percent, Cambodia and the Philippines at 16 percent, and Thailand and Vietnam at 12 percent.

Fisheries activities in both fresh water and sea water could be severely affected. Fisheries at higher elevations are likely to be adversely affected by lower availability of oxygen due to a rise in surface air temperatures. In the plains, the timing and amount of precipitation could also affect the migration of fish species from the river to the floodplains for spawning, dispersal, and their growth (FAO 2003). Sea level rise and changes in sea water temperature, salinity, wind speed and direction, strength of upwelling, mixing layer thickness and predator response to climate change have the potential to substantially alter fish breeding habitats and food supply for fishes and ultimately the abundance of fish populations in Asian waters with associated impacts on coastal economies (Cruz et al. 2007).

If Southeast Asia fails to engage in sustainable development practices and disaster risk management, regional growth and poverty eradication will be severely impacted. While many Southeast Asian countries have taken steps to tackle the impacts of climate change, more needs to be done to protect people, livelihoods and economies. The region needs to employ a number of adaptation measures, encouraging low-carbon growth, raising public awareness, funding additional climate change research, and enhancing policy planning. In the longterm, this might help to mitigate the effects of climate change, and in return, help safeguard regional economies and livelihoods.

Ecological infrastructure involves using natural landscapes and ecosystems for the benefit of society. In the case of climate change, natural landscapes that mitigate the consequences of flooding, water salinization, and erosion may be both cost effective and more resilient than traditional infrastructure, such as levies and pumps. Residents of India and Bangladesh 
have been innovating ecological infrastructure due to lack of formal structures in many areas.

\section{Xiv. Conclusion}

The climate change is resulting due to the impact of global warming phenomenon induced by greenhouse gases emissions. The predictions of change in global average temperatures due to climate change by the year 2100, ranges from a minimum temperature rise of about $1.4^{\circ} \mathrm{C}$ to as much as $5.8^{\circ} \mathrm{C}$. The effects of global warming have also caused damage to coastal infrastructure, aquaculture and coastal tourism. The natural ecosystem such as grass lands, aquatic ecosystems like mangroves and coral reefs have also been affected by the climatic change. The global climate change would impact natural biodiversity, productivity, ice deposits on mountains and polar glaciers, sea level rise, economic activities and infrastructure in coastal areas, human health, etc. The process of global warming has affected South Asia and Southeast Asian countries intensely, destroying its economy and depriving its people of their basic needs like food and shelter. The current patterns of destructive floods, increasing intensity of cyclones, recurring droughts and the increasing temperatures are all the results of global warming.

\section{References Références Referencias}

1. IPCC Fifth Assessment Report, Summary for Policymakers (2014)

2. B.D. Santer et.al., "A search for human influences on the thermal structure of the atmosphere," Nature vol 382, 4 July 1996, 39-46

3. Cruz R V, Harasawa $H$, Lal M, Wu S, Anokhin $Y$, Punsalmaa B, Honda $Y$, Jafari M, Li C and Huu Ninh N. (2007). Asia Climate Change 2007: Impacts, Adaptation and Vulnerability. Contribution of Working Group II to the Fourth Assessment Report of the Intergovernmental Panel on Climate Change, Parry M L, Canziani O F, Palutikof $J \mathrm{P}$, van der Linden $\mathrm{P} J$ and Hanson C E (eds). Cambridge University Press. Cambridge, UK. pp. 469 - 506.

4. Christensen, J.H., B. Hewitson, A. Busuioc, A. Chen, X. Gao, I. Held, R. Jones, R.K. Kolli, W.-T. Kwon, R. Laprise, V. Magaña Rueda, L. Mearns, C.G. Menéndez, J. Räisänen, A. Rinke, A. Sarr and P. Whetton, 2007: Regional Climate Projections. In: Climate Change 2007: The Physical Science Basis. Contribution of Working Group I to the Fourth Assessment Report of the Intergovernmental Panel on Climate Change [Solomon, S., D. Qin, M. Manning, Z. Chen, M. Marquis, K.B. Averyt, M. Tignor and H.L. Miller (eds.)]. Cambridge University Press, Cambridge, United Kingdom and New York, NY, USA. (https://www.ipcc.ch/site/assets/uploads/2018/02/ ar4-wg1-chapter11-1.pdf)

5. Gabriele C. Hegerl, "Detecting Greenhouse-GasInduced Climate Change with an Optimal Fingerprint Method," Journal of Climate, v. 9, October 1996, 2281-2306.

6. V. Ramaswamy et.al., "Anthropogenic and Natural Influences in the Evolution of Lower Stratospheric Cooling," Science 311 (24 February 2006), 11381141.

7. B.D. Santer et.al., "Contributions of Anthropogenic and Natural Forcing to Recent Tropopause Height Changes," Science, vol. 301 (25 July 2003), 479483.

8. Boonpragob, K., Santisirisomboon, J. (1996) Modeling potential changes of forest area in Thailand under climate change. Water Air Soil Pollution, 92, 107-117. https://doi.org/10.1007/BF00 175557.

9. National Research Council (NRC), 2006. Surface Temperature Reconstructions For the Last 2,000 Years. National Academy Press, Washington, D.C. http://earthobservatory.nasa.gov/Features/GlobalW arming/page3.php

https://www.ipcc.ch/pdf/assessment-report/ar5/syr/ AR5 SYR FINAL SPM.pdf

10. Church, J. A. and N.J. White (2006), A 20th century acceleration in global sea level rise, Geophysical Research Letters, 33, L01602, doi: 10.1029/ 2005GL024826.

https://www.ncdc.noaa.gov/indicators/

http://www.cru.uea.ac.uk/cru/data/temperature

http://data.giss.nasa.gov/gistemp

https://www.giss.nasa.gov/research/news/20170118/)

11. Levitus, et al, "Global ocean heat content 19552008 in light of recently revealed instrumentation problems," Geophysics. Res. Lett. 36, L07608 (2009).

12. L. Polyak, et.al., "History of Sea Ice in the Arctic," in Past Climate Variability and Change in the Arctic and at High Latitudes, U.S. Geological Survey, Climate Change Science Program Synthesis and Assessment Product 1.2, January 2009, chapter 7.

13. R. Kwok and D. A. Rothrock, "Decline in Arctic sea ice thickness from submarine and ICESAT records: 1958-2008," Geophysical Research Letters, v. 36, paper no. L15501, 2009.

http://nsidc.org/sotc/sea ice.html

National Snow and Ice Data Center

World Glacier Monitoring Service

14. "Attribution of Extreme Weather Events in the Context of Climate Change," National Academies Press, 2016. 
https://www.nap.edu/read/21852/chapter/1

15. Kunkel, K. et al, "Probable maximum precipitation and climate change," Geophysical Research Letters, (12 April 2013) DOI: 10.1002/grl.50334

16. Kunkel, K. et al, "Monitoring and Understanding Trends in Extreme Storms: State of the Knowledge," Bulletin of the American Meteorological Society, 2012.

http://lwf.ncdc.noaa.gov/extremes/cei.html

http://www.pmel.noaa.gov/co2/story/What + is + Oce an+Acidification\%3F

http://www.pmel.noaa.gov/co2/story/Ocean+Acidification

17. C. L. Sabine et.al., "The Oceanic Sink for Anthropogenic CO2," Science vol. 305 (16 July 2004), 367-371

18. C. Derksen and R. Brown, "Spring snow cover extent reductions in the 2008-2012 period exceeding climate model projections," GRL, 39:L19504

http://nsidc.org/cryosphere/sotc/snow_extent.html http://globalriskinsights.com/2015/11/theeconomic-impact-of-climate-change-in-southeast -asia/ (visited on 26/04/2019)

http://www.takepart.com/flashcards/what-is-climatechange/ (visited on 27/04/2019)

http://www.livescience.com/topics/global-warming (visited on 27/04/2019)

https://www.americanprogress.org/issues/security/r eports/2012/12/03/46382/climate-change-migrationand-conflict-in-south-asia/) (visited on 27/04/2019)

https://climate.nasa.gov/evidence/ (visited on 27/04/2019)

19. GUO H.-D. et al., Advances in Climate Change Research 6 (2015), p.p. 108-117

20. ZHANG R.-H., Advances in Climate Change Research 6 (2015), p.p. 131-140

21. GAO Y., Advances in Climate Change Research 7 (2016), p.p. 235-240

22. Final Report for APN Project 2004-02-CMYMuhammed; Water Resources in South Asia: An Assessment of Climate Change-associated Vulnerability and Coping Mechanisms (2005)

23. Intergovernmental Panel on Climate Change (2001): Climate Change 2001: 'Mitigation', Contribution of Working Group III to the Third Assessment Report of the Intergovernmental Panel on Climate Change [Metz B, Davidson O, Swart R and Pan J (eds.)], Cambridge: Cambridge University Press.

24. UNFCC Report on 'Climate Change: Impacts, Vulnerabilities and Adaptation in Developing Countries'(2007).

25. IPCC, 2014: Climate Change 2014: Impacts, Adaptation, and Vulnerability. Part A:Global and
Sectoral Aspects. Contribution of Working Group II to the Fifth Assessment Report of the Intergovernmental Panel on Climate Change

26. UNFCCC; Climate Change: Impacts, Vulnerabilities and Adaptation in Developing Countries (2007). https://unfccc.int/resource/docs/publications/impact s.pdf (visited on 04/08/2020)

27. The IPCC $4^{\text {th }}$ Assessment Report: Climate Change Impacts- South Asia (https://www.ifad.org/ documents/10180/55aca6fe-7127-4c48-b63d13cfd7766527)

28. Climate Change and Food Security in South Asia (2011), book published by Springer

29. Chanchal Kumar, "Climate Change in South Asia: A Framework of Sustainable Development and Human Security." Journal of Environment Pollution and Human Health, vol. 2, no. 5 (2014): 100-109. doi: 10.12691/jephh-2-5-2

30. IFAD Annual Report (2009) https://www.ifad.org/documents/38714170/39309762/print.pdf/41ccca4d-8dbd-4308-bc5d-88b306fee 339

31. Laura Southgate, (2015) The economic impact of climate change in Southeast Asia,

(http://globalriskinsights.com/2015/11/the-economic -impact-of-climate-change-in-southeast-asia/)

32. Nipon Tangtham, (2009) Climate Change and foreseen effects and implications for South Asia

(http://www.selamat.net/upload_mm/9/a/4/a49919e 8-92bf-4f96-88a6-8b0e16feaa0d_lec3.pdf)

33. Stern, N. (2006) Stern Review: The Economics of Climate Change

(http://mudancasclimaticas.cptec.inpe.br/ rmclima /pdfs/destaques/sternreview_report_complete.pdf )

Web links visited for Additional References:

34. Global Warming: News, Facts, Causes \& Effects Live Science

(https://www.livescience.com/topics/globalwarming)

35. UNFCC Report on Climate change: impacts, vulnerabilities and adaptation in developing countries (2007) (http://envirosoc.org/Resources/ unfccc.pdf)

36. Climate Change Online Lab|Precipitation Education (https://gpm.nasa.gov/education/lesson-plans/ climate-change-online)

https://shared.spokane.edu/ccsglobal/media/Global /PDFs/SFCC/Planetarium/dynamicEarthEducatorGui de.pdf

37. Pro \& Con Quotes: Is Human Activity Primarily Responsible for Global Climate Change? (2019) https://climatechange.procon.org/is-human-activityprimarily-responsible-for-global-climate-change-procon-quotes/ 
38. Climate Change Inquiry Labs - Teacher Guide https://gpm.nasa.gov/education/sites/default/files/le sson_plan_files/climate change inquiry/Climate Change Inquiry TG.pdf

39. Global Climate Change: Vital Signs of the Planet (Climate Change: How Do We Know ?)

https://climate.nasa.gov/evidence/

40. NASA, NOAA Data Show 2016 Warmest Year on Record ...

https://www.nasa.gov/press-release/nasa-noaadata-show-2016-warmest-year-on-record-globally https://edition.cnn.com/2019/06/24/politics/mikepence-climate-crisis/index.html

https://www.coursehero.com/file/p3to8t6/httpswwwn rdcorgstoriesglobal-warming-

101gclidEAlalQobChMlzY/

https://www.coursehero.com/file/p7elj1m/Theamount-of-carbon-dioxide-absorbed-by-the-upperlayer-of-the-oceans-is/

https://climateandsecurity.org/2012/12/new-reportclimate-change-migration-and-conflict-in-southasia/

https://www.americanprogress.org/issues/security/r eports/2012/12/03/46382/climate-change-migrationand-conflict-in-south-asia/

https://books.google.com/books?id=mKKtQR4T$1 \mathrm{MC}$

https://www.challengetochange.org/climate.htm https://www.coursehero.com/file/p5uiajc/India-hasan-800-km-coastline-and-is-therefore-verysusceptible-to-cyclonic/

https://www.scribd.com/document/336293985/Glob al-Warming-and-Its-Impacts-on-Climate-of-WestBengal

41. Global Warming And Its Impacts On Climate Of India

https://www.scribd.com/document/381235046/GLO BAL-WARMING-AND-ITS-IMPACTS-ON-CLIMATEOF-INDIA-pdf

https://www.scribd.com/document/342533697/asea n-project-final

42. Climate Change Impacts - South East Asia https://studyres.com/doc/1273554/climate-changeimpacts---south-east-asia

http://uchai.net/pdf/knowledge resources/Publicatio ns/Reports/Climate Change Impacts_South Asia.pdf https://www.coursehero.com/file/p2bjqb/Habitatalteration-from-rising-temperatures-chemicalpollution-or-the/

43. The Regional Impacts of Climate Change https://www.grida.no/climate/ipcc/regional/282.htm
https://www.coursehero.com/file/psmf9j/When-theprimary-carer-is-involved-in-raising-children-orcaring-for-the/

https://www.wur.nl/upload_mm/9/a/4/a49919e8-

92bf-4f96-88a6-8b0e16feaa0d_lec3.pdf

https://www.slideshare.net/SaeedMinhas/regionalclimate-chnage-water-kashmir

44. The economic impact of climate change in Southeast Asia ...

https://globalriskinsights.com/2015/11/theeconomic-impact-of-climate-change-in-southeastasia/

45. Climate Change, Migration https://www.americanprogress.org/wp-content/ uploads/2012/11/ClimateMigrationSubContinentRep ort_small_execsumm.pdf

46. Climate Change Impacts - South Asia https://studyres.com/doc/6974029/climate-changeimpacts---south-asia

47. Extreme events; Future | Tropical Cyclones | Sea Level Rise

https://www.scribd.com/document/50406382/Extre me-events-Future

https://www.slideshare.net/veereshpatil524/climatechange-global-warming-consequenses

48. Climate change and health - World Health Organization

https://www.who.int/news-room/factsheets/detail/climate-change-and-health

https://www.sites.google.com/site/daddyindia91/cli mate-change

49. Climate change, global warming and its consequences

https://www.slideshare.net/veereshpatil524/climatechange-global-warming-and-its-consequences

50. Climate Change Impacts-South Asia

http://uchai.net/pdf/knowledge_resources/Publicatio ns/Reports/Climate\%20Change\%20Impacts_South \%20Asia.pdf

https://public.wmo.int/en/media/press-release/green house-gas-concentrations-atmosphere-reach-yetanother-high

https://www.adb.org/documents/adb-annual-report2019

https://selamat.net/upload_mm/9/a/4/a49919e892bf-4f96-88a6-8b0e16feaa0d_lec3.pdf 